\title{
The Fiscal Impacts of Urban Sprawl: Evidence from U.S. County Areas*
}

\author{
Christopher B. Goodman ${ }^{\dagger} \quad$ Northern Illinois University
}

This paper examines the fiscal impacts of urban development patterns in the United States. Previous studies have indicated low-density, spatially expansive development patterns are costly to provide public services leading to higher per capita expenditures. However, theory would suggest alternate outcomes. This question is examined using a panel dataset of U.S. urban county areas and a specification allowing for potential non-linearity between development patterns and per capita expenditures. Estimates indicate that the spatial extent of development is the most important; more compact development is less costly to provide public services. Higher density increases per capita expenditures; however, the effects are small.

Keywords: urban sprawl, population density, local government finance

\section{Introduction}

The United States is a suburban nation. From before World War II, individuals and families have been leaving central cities for areas further away from the urban core. This mass exodus has undoubtedly made the majority of the movers better off by consuming more land and housing at lower costs. Additionally, these movers were able to escape the many urban ills typical of the time: crime, noise and pollution to name a few. To an extent this trend continues (Glaeser and Kahn 2006), but there is a current debate on whether urban cores are reversing their historical population loss. Whether individuals and families are moving to the suburbs or urban cores, numerous potential economic, social and fiscal costs loom large. Of particular concern for this analysis are fiscal costs to taxpayers because of inefficiencies in suburban style development.

Much previous research has suggested that low-density outward expansion of urban areas places strain on local government finances. In particular, the costs of providing public services rise with this style of development. Costs can rise directly through diseconomies of scale or indirectly through suboptimal placement of capital infrastructure or the duplication of public services. Regardless of the cause, it is claimed that low density development far from the urban core is more expensive to provide public services than more densely developed areas. While much research has been conducted on this subject, few analyses examine the phenomena over time. The analysis presented here aims to fill this gap in the literature by examining the relationship between suboptimal urban development patterns (i.e. urban sprawl) and per capita local government expenditure over time. This is accomplished using panel data on U.S. urban county areas measured every five years from 1982 to 2012. Consistent with previous literature, a number of demand and cost related variables are included in the econometric model and the relationship between development patterns

*Preliminary Draft, Please do not cite or circulate without author's permission.

${ }^{+}$August 6, 2019 
and public spending is allowed to take on a non-linear structure. As Hortas-Rico and Solé-Ollé $(2010,515)$ notes, "[e]mpirical evidence regarding the fiscal consequences of sprawl is scarce and remains inconclusive" and this analysis extends a limited literature to include an analysis of the fiscal consequences of sprawl over time.

Additionally, this analysis provides policy relevant evidence on whether suburban or infill development should be encouraged from a fiscal perspective. The results presented below suggest that, where appropriate, infill development is likely to lead to lower per capita expenditures; however, this result is complex and not uniform across policy areas. Should the apparent resurgence of urban cores continue, it is likely these areas will enjoy somewhat lower per capita expenditures on average. This paper is organized as follows. In section 2, the previous research on the causes and consequences of urban sprawl are examined with a particular emphasis on local public finance implications. In section 3 the econometric model and data for this analysis are presented and discussed. Section 4 presents the results of the estimation. Finally, policy recommendations are offered.

\section{Previous Research}

\section{Measuring Sprawl}

The economics and urban planning literature take very different views of what constitutes an appropriate measurement of urban sprawl. As Brueckner $(2000,161)$ defines it, urban sprawl is "excessive spatial growth of cities." In other words, cities have grown horizontally or outwardly to an inefficient extent. Brueckner is careful to point out that spatial growth of cities is a necessary but insufficient condition for urban sprawl. Only excessive growth as the result of three specific market failures is indicative of urban sprawl. Urban planners present a contrasting definition of urban sprawl that includes a number of facets. Burchell et al (1998) cites ten dimensions, Galster et al. (2001) cites eight dimensions, and Duany, Plater-Zyberk, and Speck (2000) cites five dimensions. Ewing (1994) encapsulates the urban planning perspective on urban sprawl as development patterns that are low density and/or scattered, poorly connected to jobs and retail, and lacking in functional open-space.

For this analysis, I take an approach from the economics literature in constructing relevant measures of urban sprawl given data availability. Similar to Carruthers and Úlfarsson $(2003,2008)$, Hortas-Rico and Solé-Ollé (2010), Glaeser and Kahn (2006), Nechyba and Walsh (2004), and Wassmer (2008), density is the primary operationalization of urban sprawl. As Wassmer (2008) mentions, most Americans identify low density as the primary characteristic of urban sprawl. Density is primarily a vertical measure, indicating how many individuals and/or jobs are contained within a spatial area. However, the size of the spatial area is also important as this (1) influences density and (2) influences the extent to which horizontal growth has taken place (i.e. the extent to which a countys growth is decentralized). To account for this, a second variable is introduced, urban land area, to control for this horizontal dimension of sprawl.

As Wassmer (2008) and Wolman et al. (2005) note, the appropriate geographic scale at which urban sprawl should be measured is difficult to get right. County-based measures will "overbound," including some rural land area that is not connected to urban activity and is unlikely to develop. Using Census defined urbanized areas is likely to "underbound" the problem by missing land on the urban fringe that is likely to develop soon. Wolman et al. (2005) solves this potential issue by constructing an Extended Urban Area consisting of Census Bureau defined urbanized ar- 
eas and adding outlying land to account for potentially developable land. Unfortunately, the data requirements to make this adjustment to urbanized areas (Census block level data) are unavailable for the years of this analysis. However, to attempt to mitigate the potential overbounding problem, urbanized land is utilized as a conservative estimate of the spatial extent of sprawl. This is consistent with the approaches of Carruthers and Úlfarsson (2003, 2008), Hortas-Rico and SoléOllé (2010), and Wassmer (2008).

The most comprehensive data source for developed or urbanized land in the U.S. is the National Resource Inventory (NRI) conducted by the U.S. Department of Agriculture in concert with Iowa State University. The NRI derives major land use categories from observational data from 1982, 1987, 1992, 1997, and annually beginning in 2000. ${ }^{1}$ While primarily interested in tracking changes in crops and natural land coverings, the NRI tracks changes in urban or developed lands. These data are well suited for an examination of urban development as they include residential, commercial, and industrial uses plus other large uses including transportation networks, small parks, and those lands that do not conform to this definition to are surrounded by urban uses. It captures the urban, suburban and exurban fabric of metropolitan areas of the United States over a reasonably long time period. In previous research, the U.S. Census Bureau's urbanized land or NRI urban or developed land have been used. Carruthers and Úlfarsson (2008) cover the difference between these two data sources and concludes that the NRI is a reasonable measure of land use patterns with limited differences from the Census Bureau's urbanized land data. ${ }^{2}$

As mentioned above, urban sprawl is operationalized using two variables. First and the most common measure of urban development patterns is density, measured as the number of individuals and jobs per acre of developed land. Urban development patterns rely on both residential and non-residential uses (Carruthers and Úlfarsson 2003); therefore, the inclusion of both the residential population and daytime, working population is a more realistic portrayal of density. ${ }^{3}$ Density implicitly measures the vertical aspect of development. The second measure of urban development patterns is the percentage of county land area that is developed. This measures the horizontal aspect of urban development indicating how much of a county's land area has been converted from non-intensive agricultural or natural uses to more intensive, urban-like uses. As mentioned by Carruthers and Úlfarsson (2003) and Wassmer (2008), measuring urban sprawl in this two-dimensional manner is somewhat limited, lacking the ability to capture variation in urban form between specific places within a county. The purpose of these two operationalizations is to measure the variation in overall patterns in urban sprawl rather than the characteristics of any specific area in an urban county. Before any causal augments can be made the fiscal impacts of urban sprawl on particular parcels or sub-county areas, this analysis needs to be repeated on a multi-faceted operationalization of urban sprawl similar to that of Galster et al. (2001) that can capture the characteristics of those specific areas.

Figure 1 displays the percent change of the two sprawl-related variables between 1982 and 2012. Panel (a) shows the change in developed land is quite high across the southern and western states with numerous county areas experiencing changes of more than 100 percent. This follows overall population growth patterns in the United States over this time period as individuals and

\footnotetext{
${ }^{1}$ See Nusser and Goebel (1997) for a complete description of the sampling and data collection procedures of the NRI.

${ }^{2}$ Carruthers and Úlfarsson (2008) indicate that in 80 percent of the data, the difference between urbanized land and the NRI is less than five percent.

${ }^{3}$ In an ideal world, one would be able to measure each form of density separately (population divided by residential land area; employment divided by non-residential land area). Unfortunately, the "developed land" category from the NRI cannot be disaggregated further.
} 


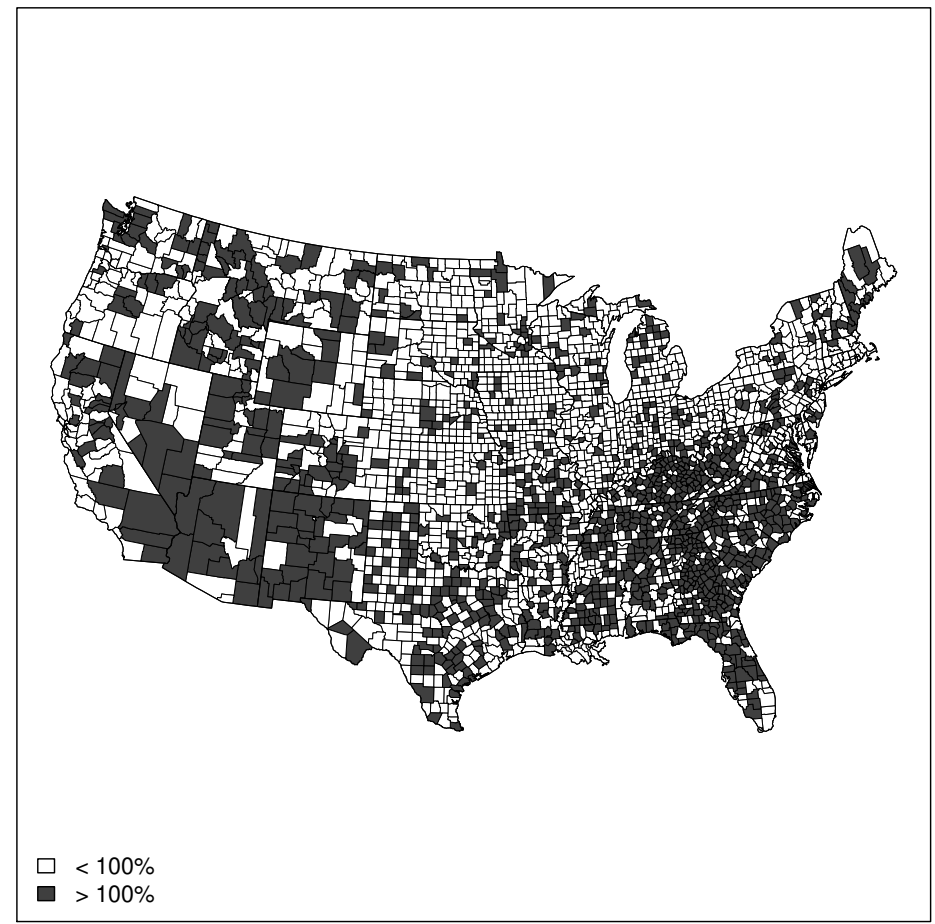

(a) Change in developed land (\%)

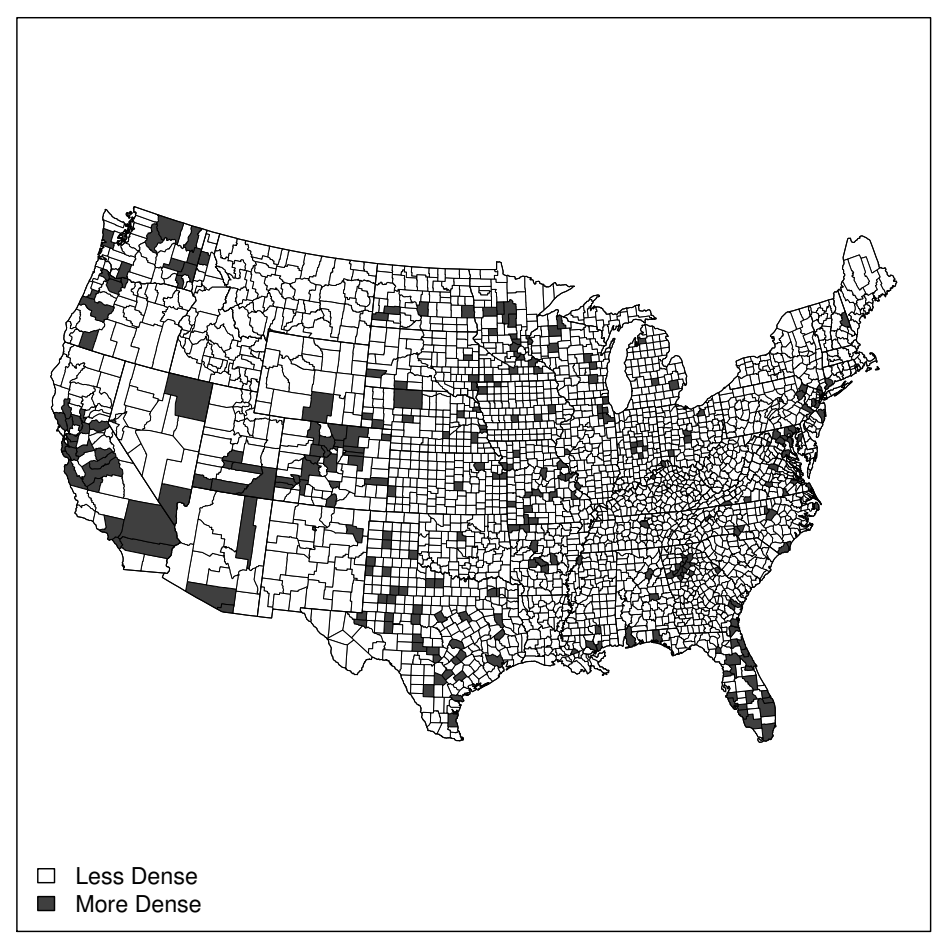

(b) Change in density

Figure 1: Changes in land use patterns, 1982-2012 
households moved from the northeast and upper Midwestern regions to the south and western regions. As panel (b) shows, much of this growth is horizontal in nature. Although large portions of the southern and western regions increased the amount of developed land, densities only rose in a handful of counties in this region. These are largely clustered in major metropolitan employment centers. Combined, these two maps suggest that both the vertical and horizontal aspects are important in our understanding of how areas develop.

\section{Sprawl \& Local Public Finance}

At its core, urban sprawl is excessive or inefficient suburbanization. Brueckner (2000) suggests this excessive spatial growth is the result of three primary market failures. The first is the failure to consider the social value of open space. This leads to overzealous conversion of land to urban uses. The second is the failure of individuals to consider the social cost of their commuting patterns leading to "excessive commuting and cities that are too large" (Brueckner 2000, 163). The final is the failure of developers to consider all the public costs of their projects. As (Brueckner 2000) mentions, this final failure leads to "artificially cheap" developments on the urban fringe resulting in excessive growth. This final market failure is the specific focus of this analysis. ${ }^{4}$

While research has shown that development impact fees can partially offset the final market failure (Brueckner 1997), ${ }^{5}$ the failure to incorporate public service costs into development costs can increase the cost of providing public services. The literature suggests that sprawl is costlier to provide public services because this type of development pattern fails to capitalize on economies of scale (Carruthers and Úlfarsson 2002, 2003), often fails to optimize the location of costly capital facilities (Carruthers and Úlfarsson 2002, 2003), and leads to duplicative service delivery (Real Estate Research Corporation 1974). More compact development patterns can help to contain these costs.

Alternatively, increased density, one aspect of compact development, has been suggested to increase the cost of providing public services. The reasoning for this is twofold: economies of density could indeed lower per capita local costs and, therefore, per capita expenditures; however, the increased "harshness" of the urban environment associated with increased density could lead to higher per capita costs and expenditures (Ladd 1992). The intuition behind economies of density is simple; as average density rises, the average cost of providing public services falls because residents are grouped closer together allowing for economies of density. The result of this would be falling per capita expenditures. However, per capita expenditures can rise due to the ?harshness? of the urban environment. Urban areas are "harsh" because costs are higher to provide the same level of public output than lower density areas (Bradbury et al. 1984; Ladd 1992, 1994). For example, to provide a similar level of traffic safety, dense, urban areas require more traffic lights, pedestrian equipment, signage, etc. because the density of the transportation network relative to less dense, more suburban areas. Additionally, denser areas tend to have higher land prices and, to the extent that public services rely on land in their production function, these higher land prices will translate into higher expenditures (Ladd 1994). Urban "harshness" has

\footnotetext{
${ }^{4}$ Numerous analyses have suggested other mechanisms as to how sprawl has proliferated. These include natural urban development patterns (Brueckner and Fansler 1983) including transportation infrastructure (Baum-Snow 2007a, 2007b), "flight from blight" (Mieszkowski and Mills 1993), and tax policies (Brueckner and Kim 2003; Song and Zenou 2006). Additionally, a number of analyses tackle this issue from multiple perspectives (Burchfield et al. 2006; Wassmer 2008).

${ }^{5}$ There is some disagreement on this point (Burge and Ihlanfeldt 2006).
} 
been considered to be an environmental cost as envisioned by Bradford, Malt, and Oates (1969) in numerous studies (Bradbury et al. 1984; Ladd 1992, 1994; Ladd and Yinger 1989).

Given the theoretical evidence above, there are multiple expectations as to the fiscal impact of urban sprawl. More compact development can potentially lead to lower per capita costs (and expenditures); however, rising density may lead to increasing per capita costs (and expenditures). A number of empirical studies on both side of the issue have attempted to sort out the relationship between sprawl and per unit costs. Carruthers and Úlfarsson $(2003,2008)^{6}$ find in both of their analyses a negative relationship between density (measured as person and jobs per urbanized acre) and per capita local expenditures after taking into account the spatial extent of urbanized land and property values. This trend is persistent across expenditure categories (Carruthers and Úlfarsson 2003) and after taking into account potential spatial dependencies (Carruthers and Úlfarsson, 2008). Similarly, Hortas-Rico and Solé-Ollé (2010) ${ }^{7}$ find that land per person is positively associated with per capita costs of public services. Specifically, they find that "per capita local costs have increased on average by 2.3 percent due to the impact of urban sprawl" (Hortas-Rico and Solé-Ollé 2010, 1534).

The typical finding in the economics literature is that increased density increases per capita public service costs at all or most levels of density. Bradbury et al. (1984) find a positive and significant relationship between population density and per capita expenditures. In more recent literature, Ladd (1992, 1994, 1998), modeling a piecewise regression, finds that population density has a U-shaped relationship with per capita expenditures. Rising density first lowers per capita expenditures to a point, after which, per capita expenditures rise with population density. This relationship is persistent across different expenditure types including current expenditures and capital expenditures (Ladd 1992). Additionally, Holcombe and Williams (2008) find, allowing population density to be endogenously determined, that density is only positive and significantly influential on per capita expenditures for municipalities with populations above 500,000 residents. However, when sewer expenditures are considered alone, there is a negative relationship between density and per capita expenditures. Given this disagreement in the literature, further empirical study is warranted.

\section{Empirical Strategy \& Data}

Previous literature on relationship between urban development patterns and public expenditures identify several important factors. Ladd $(1992,1994)$ and Hortas-Rico and Solé-Ollé (2010) suggest that both demand for public services as well as the costs of providing such services are important in the determination of the level of public spending. Demand related influences typically include many of those suggested by Bergstrom and Goodman (1973) and Borcherding and Deacon (1972), primarily income endowments, tax price and preferences for local public services. Costs may take the form of development patterns directly or can take the form of input costs or environmental costs (Bradford, Malt, and Oates 1969). Underlying both demand and cost concerns is the issue of the assignment of service delivery responsibilities in an intergovernmental system (Ladd and

\footnotetext{
${ }^{6}$ Carruthers and Úlfarsson $(2003,2008)$ estimate a strictly linear relationship of density and per capita expenditures.

${ }^{7}$ Hortas-Rico and Solé-Ollé (2010) estimate a piecewise relationship of urbanized land and per capita expenditures. As such, urbanized land does not enter into the model as a continuous variable. Rather, urbanized land enters as a series dummy variables measuring individual segments on the overall trend.
} 
Yinger 1989). In those states in which the state government is more active in providing public services, the need for local public spending is tempered.

Drawing on the collective research above, the following model is specified.

$$
e=f(\mathbf{U}, \mathbf{D}, \operatorname{var}(\mathbf{D}), \mathbf{C}, \mathbf{A})
$$

Where per capita expenditures, $e$, is a function of urban development patterns $(\mathbf{U})$ and various control variables. Following Carruthers and Úlfarsson $(2003,2008)$, the two variables comprising urban development patterns are defined as follows: population plus employment density and the percentage of a county that is considered developed. Demand for public services (D) includes per capita income and the percentage of the revenues from property tax (a proxy for tax price) and the variation in demand $(\operatorname{var}(\mathbf{D}))$ is measured by a Leik (1966) index of race and age. The cost of providing public services $(\mathbf{C})$ includes population and population growth, the prevalence of various age groups, employment per capita and average local government wage. Assignment of service delivery responsibilities (A) is measured by federal aid per capita, state aid per capita, general purpose local governments per capita, special districts per capita, and the functional performance index ${ }^{8}$ as calculated by Berry (2009). After controlling for the demand for public services, variation in these demands, factors influencing the cost of providing public services and the service delivery environment of the local area, the remaining influence is attributable to the two variables measuring urban development patterns. Appendix A2 provides the definition of each independent variable outlined above, their means and standard deviations. All variables in dollars have been adjusted to 2005 dollars using the CPI deflator.

As Carruthers and Úlfarsson (2003) explain, the exact functional form that equation 1 should take is a matter of debate in the extant literature. Linear (Hortas-Rico and Solé-Ollé 2010), semi-log (Carruthers and Úlfarsson 2003, 2008), and a partial log-linear (Ladd 1992) specification have all been taken in the literature. After much testing and following recent research by Carruthers and Úlfarsson $(2003,2008)$, a semi-log specification of equation 1 is as follows.

$$
\ln e_{i t}=\alpha+\gamma D E N_{i t}+\delta D E V_{i t}+\boldsymbol{\beta} \mathbf{x}_{i t}+\phi_{i}+\tau_{t}+\varepsilon_{i t}
$$

Where the natural log of per capita expenditures for county $i$ in time $t$ is a function of the vector of urban development variables, density $(D E N)$ and percent developed $(D E V)$, and control variables explained above $(\mathbf{x})$, county-specific, time invariant fixed effects $\left(\phi_{i}\right)$, year fixed effects $\left(\tau_{t}\right)$ common to all observations in time $t$, and the usual error term $\left(\varepsilon_{i t}\right)$. County level fixed effects are a unique contribution of this analysis, effectively controlling for county-specific unobservables. ${ }^{9}$ There are a number of time-invariant factors that influence urban sprawl and their exclusion can lead to an omitted variable bias. Two such important factors are local zoning regimes (Pendall 1999) and

\footnotetext{
${ }^{8}$ This variable is included to control for any possibility that less dense county areas intentionally provide lower levels of public services. Following Berry (2009), this variable is calculated as

$$
F P I_{j t}=\sum_{i t} \alpha_{i j t} \mu_{i t}
$$

where $i$ represents functional spending categories (defined by the Census Bureau, 35 in total), $j$ represents county areas, and $t$ represents years. $\alpha_{i j t}$ is equal to 1 if county area $j$ has positive spending on service $i$ in year $t$ and 0 otherwise. $\mu_{i t}$ is equal to the national median spending on service $i$ in year $t$ among all county areas in which the service is provided. FPI will increase if a county area provides an additional service or the national median spending on a service increases.

${ }^{9}$ Carruthers and Úlfarsson $(2003,2008)$ include state fixed effects, Holcombe and Williams (2008) include city size fixed effects, and Hortas-Rico and Solé-Ollé (2010) do not include any fixed effects.
} 
geography (Burchfield et al. 2006). ${ }^{10}$ Insomuch as preferences for suburbanization are constantly over time by location, county-specific fixed effect may also control for preferences. However, given migration, this is unlikely to hold. In this case, the control variables in $\mathrm{x}$ attempt to control for preferences and the remaining unobservables are relegated to the error term. This model is estimated over eleven expenditure categories $\left(e_{i t}\right)$ and their definitions can be found in appendix A1. ${ }^{11}$ The primary analysis is conducted on per capita current expenditures ${ }^{12}$ that represents both expenditures for current operations plus debt service that represents the annualized cost of long term assets such that they are debt financed. The remaining ten expenditure categories represent large spending categories for U.S. local governments.

As explained by Ladd (1992) and Hortas-Rico and Solé-Ollé (2010), the exact relationship between urban development and per capita expenditures is unknown. In both analyses, population density enters into the estimating equation in a piecewise manner allowing for density to take on a non-linear form. The use of county-level fixed effects in this analysis does not allow for such an estimating technique. Instead, a hybrid specification strategy is chosen. First, density is entered into equation 2 in a linear fashion. ${ }^{13}$ Both positive and negative signs have been found in the literature, so it is difficult to make a prediction, a priori. A negative sign would be consistent with the "Smart Growth" concept where rising density leads to per capita public cost savings (Carruthers and Úlfarsson 2008). However, it is also possible that rising density be associated with increased urban "harshness" leading to higher per capita public costs and therefore increased per capita expenditures (Ladd 1992).

$$
\ln e_{i t}=\alpha+\gamma D E N_{i t}+\delta_{1} D E V_{i t}+\delta_{2} D E V_{i t}^{2}+\delta_{3}\left(D E V_{i t}-u_{i}\right)^{2}+\beta \mathbf{x}_{i t}+\phi_{i}+\tau_{t}+\varepsilon_{i t}
$$

The influence of the horizontal aspect of development, the percentage of county land that is developed, suggests a similarly complex relationship with per capita expenditures.Carruthers and Úlfarsson $(2003,2008)$ suggests that lower percentages are more indicative of compact development with less leap frog or discontinuous development. However, extremely high values of this variable suggest the same result when the entire county is completely developed. Therefore, it is possible that high and low values of development are indicative of "compact" development. These two potentialities suggest a non-linear relationship between development and per capita expenditures. This relationship is a global one; examining the change in "compactness" on average change in per capita expenditures. However, within county changes in "compactness," i.e. changes in compactness around a county specific mean, may also be important and their exclusion could bias the estimate of the global nonlinearity. Following Ihlanfeldt and Willardsen (2018),

\footnotetext{
${ }^{10}$ Geography is certainly the most time-invariant; however, many local zoning ordinances remain virtually unchanged over long periods of time.

${ }^{11}$ For the ten specific expenditure categories, the natural log transformation is problematic as there are many county areas with zero expenditures for categories. Rather than dropping such observations, the ten categories are transformed by the inverse hyperbolic sine that is robust to zeros and interpretable in the same manner as natural logs. See Burbridge, Magee, and Robb (1988) for more information.

${ }^{12}$ It is important to note that public expenditures are a combination of the number of units of public services demanded times the cost to provide those services. Because of the price elasticity of demand will lead local areas to demand fewer units of public services in the face of higher costs, the estimates to follow are likely a lower bound to the "true" effect of urban sprawl on public costs. Thank you to an extremely helpful reviewer for pointing this out.

${ }^{13}$ The decision to enter density into the estimating equation linearly was made after much testing for potential nonlinearities. In all specifications, density, its (global) square, and the demeaned (within) square are not statistically significant (individually or jointly). I ultimately conclude there is no non-linear relationship between density and per capita expenditures.
} 
McIntosh and Schlenker's (2006) hybrid solution is used where the square of difference between development and its county specific mean is entered into the estimating equation $\left(\delta_{3}\right.$ in equation 3). If the within nonlinearities are important, this strategy effectively eliminates the potential bias. However, if they are not, equation 3 simply reverts to equation 2. In all instances, the global nonlinearity is the important relationship; however, the within nonlinearity is shown in table 1 to demonstrate its importance in some estimates.

Equation 3 is estimated using data from 1982 to 2012 in 5-year increments on U.S. county areas in the contiguous United States belonging to a metropolitan statistical area in 2013. ${ }^{14}$ This is an attempt to eliminate some of the problems with underbounding or overbounding as explained by Wolman et al. (2005). By fixing the extent of the metropolitan area at the end of the time period, developable land on the urban fringe in earlier time periods is entered into the estimation. This is particularly true for fast growing, spatially large metro areas in the southern and western portions of the county. As a result of this data structure, a correlation in errors between counties in the same metropolitan area is introduced. To eliminate this potential source of bias, standard errors are clustered on the metropolitan area. ${ }^{15}$

Following Ihlanfeldt and Willardsen (2018), a number of specification tests are conducted. First, joint tests of significance are conducted on the percent developed variables. In six of the eleven specifications from table 2, the joint F-test suggests nonlinearities. However, for libraries, housing \& community development, roadways, natural resources, and parks \& recreation, the joint F-test rejects nonlinearity. The null hypothesis is rejected for all specifications in table 1 suggesting nonlinearity. Second, a joint F-test is conducted for both density and percent developed (and its square) to establish is the dual variable approach is warranted. In all specifications, the null hypothesis of no joint relationship is rejected. Third, a joint test of significance of the countylevel fixed effects is conducted. The results of this test confirm the joint significance of the county level fixed effects in all specifications from table 1 and 2. Lastly, testing for strict exogeneity by conducted a joint F-test on $t+1$ leading explanatory variables as suggested by Ihlanfeldt and Willardsen (2018) is inconclusive for many of the specifications. This result suggests the potential for simultaneity bias; however, Wooldridge (2010) contends the bias resulting from violating strict exogeneity in a long panel is minimal. ${ }^{16}$

\section{Results}

Table 1 shows the results of four regressions in which the dependent variable is natural log of current expenditures, aggregated over all governments in a county, per capita. The first specification is a pooled regression with year fixed effects most similar to equation 2 . The second specification fully estimates equation 3 with county and year fixed effects and the within nonlinearity. This specification is preferred. The third specification estimates equation 3 using Driscoll and Kraay (1998) standard errors to explore the influence of cross-sectional dependence on the results. Ad-

\footnotetext{
${ }^{14} \mathrm{~A}$ county area is a composite of all local government activity within the borders of the county. Additionally, a number of independent cities in Virginia are eliminated from the analysis because of their unique governmental structure. These eliminations from the data lead to an unbalanced panel of 7,670 observations across 1,111 county areas.

${ }^{15}$ Cross-sectional dependence among the errors may also be a problem. Testing using the Stata XTCD2 command suggests the presence of some cross-sectional dependence. To explore the influence of this, a model is estimated in table 1 using Driscoll-Kraay (1998) standard errors that are robust to this type of correlation.

${ }^{16}$ This statement does not seek to minimize the potential for endogeneity. However, given the cross-sectional breadth and length of the panel, sufficient instruments are not available.
} 
justing the standard errors to be robust to cross sectional dependence has served to reinforce the primary results from specification two. Finally, the fourth specification introduces state-year time trends to control for any state-specific, shared shocks that evolve over time. ${ }^{17}$ Generally, the results for specifications two through four are similar.

The results in table 1 indicates a positive and statistically relationship between density and per capita current expenditures in models with county-level fixed effects. The magnitude of the effect size is small with a one person or job per acre increase in density associated with a 0.2 percent increase in per capita current expenditures on average. This relationship holds regardless of the functional form of percent developed land and estimation strategy. This small yet positive finding is supportive of the urban harshness perspective put forward by Ladd (1992). As an area becomes denser, the close proximity of people, buildings, and all the other assets required to deliver public services drive up the cost of doing so. It is likely this low rate of change in per capita expenditures with respect to density could easily be accounted for by increased revenue productivity in dense urban areas. This result is contrary to that found by Carruthers and Úlfarsson $(2003,2008)$ though it is unclear if this positive finding is a negative for the smart growth perspective given the small magnitude of the effect size.

Across all four specifications in table 1, the relationship between the percentage of county area that is developed is nonlinear and inverse $u$-shaped. Specifications one, two and three demonstrate that as development moves from zero to approximately 48 percent ${ }^{18}$ developed, per capita current expenditures increases. Specification 4, including state-year time trends, suggests a more truncated relationship with the turning point at seven percent developed. These findings suggest the following relationship. As development progresses outward, it likely moves in a haphazard or leapfrog manner, increasing the costs of providing public services. However, after a certain point (48\% developed), easily developable greenfields are exhausted and infill development begins. The filling in of the urban/suburban fabric lowers per capita costs as there are not large open gaps to traverse and it becomes easier to efficiently locate fixed public service assets. Graphically, this relationship can be seen in the upper left panel of figure 2. The remainder of the control variables are consistent with the extant literature and not interpreted due to space limitations.

In table 2, equation 3 is estimated on ten categories of per capita current expenditures. In a similar fashion to Carruthers and Úlfarsson $(2003,2008)$ and Hortas-Rico and Solé-Ollé (2010) to examine if the influence of the two sprawl related variables change across a variety of policy areas. These categories are the same as the nine categories used in Carruthers and Úlfarsson (2008) with the inclusion of an additional category, natural resources. As such, this analysis can provide a comparison to the results found by Carruthers and Úlfarsson when the influence of time is included in the analysis. The full regression results can be found in appendix A3. The influence of developed land can be seen graphically in figure 2 .

What is clear from the results in table 2 and figure 2 is that various policy areas are not impacted by urban development patterns in a uniform manner. For many policy areas, either density or percent developed fail to achieve statistical significance. For housing and community development and parks and recreations, neither measure of urban development is statistically significant. This confusing set of results is expected as different policy areas are likely influence by the two aspects of urban development different. For example, density appears unrelated to fire expenditures

\footnotetext{
${ }^{17}$ Thank you to anonymous reviewer 2 for this suggestion.

${ }^{18}$ The exact inflection points are 47.1 percent for specification one, 48.9 percent for specifications two and three, and 7.1 percent for specification four.
} 
Table 1: OLS estimates of per capita current expenditures equations

\begin{tabular}{|c|c|c|c|c|}
\hline Variable & $(1)$ & $(2)$ & (3) & (4) \\
\hline Density & $\begin{array}{c}0.0001 \\
(0.33)\end{array}$ & $\begin{array}{c}0.0020^{*} \\
(2.16)\end{array}$ & $\begin{array}{c}0.0020^{* *} \\
(3.93)\end{array}$ & $\begin{array}{c}0.0019 * \\
(2.22)\end{array}$ \\
\hline Percent developed & $\begin{array}{c}0.6323^{* *} \\
(5.33)\end{array}$ & $\begin{array}{c}0.6952^{* *} \\
(4.04)\end{array}$ & $\begin{array}{c}0.6952^{* *} \\
(10.70)\end{array}$ & $\begin{array}{c}0.0939 \\
(0.51)\end{array}$ \\
\hline Percent developed $^{2}$ (global) $^{\mathrm{a}}$ & $\begin{array}{c}-0.6718^{* *} \\
(4.97)\end{array}$ & $\begin{array}{c}-0.7104^{* *} \\
(3.02)\end{array}$ & $\begin{array}{c}-0.7104^{* *} \\
(9.92)\end{array}$ & $\begin{array}{c}-0.6625^{* *} \\
(2.96)\end{array}$ \\
\hline Percent developed $^{2}$ (within) ${ }^{b}$ & - & $\begin{array}{c}-1.7804 \\
(1.39)\end{array}$ & $\begin{array}{c}-1.7804^{* *} \\
(4.82)\end{array}$ & $\begin{array}{c}-3.4687^{*} \\
(2.30)\end{array}$ \\
\hline Personal income, per capita & $\begin{array}{c}0.0042 \\
(1.52)\end{array}$ & $\begin{array}{c}0.0038^{* *} \\
(2.66)\end{array}$ & $\begin{array}{c}0.0038^{* *} \\
(4.09)\end{array}$ & $\begin{array}{c}0.0046^{* *} \\
(2.93)\end{array}$ \\
\hline Percent property tax & $\begin{array}{c}-0.2735^{* *} \\
(5.71)\end{array}$ & $\begin{array}{c}-0.5943^{* *} \\
(6.79)\end{array}$ & $\begin{array}{c}-0.5943^{* *} \\
(7.31)\end{array}$ & $\begin{array}{c}-0.7214^{* *} \\
(7.76)\end{array}$ \\
\hline Variation in race & $\begin{array}{c}0.0364 \\
(0.62)\end{array}$ & $\begin{array}{c}-0.4592^{* *} \\
(3.37)\end{array}$ & $\begin{array}{c}-0.4592^{* *} \\
(8.17)\end{array}$ & $\begin{array}{c}-0.2345 \\
(1.86)\end{array}$ \\
\hline Variation in age & $\begin{array}{l}1.0475 \\
(0.96)\end{array}$ & $\begin{array}{c}0.2962 \\
(0.70)\end{array}$ & $\begin{array}{c}0.2962 \\
(1.29)\end{array}$ & $\begin{array}{c}0.9144^{*} \\
(2.35)\end{array}$ \\
\hline Population (1000s) & $\begin{array}{c}-0.0000 \\
(1.84)\end{array}$ & $\begin{array}{c}0.0002 \\
(1.79)\end{array}$ & $\begin{array}{c}0.0002^{* *} \\
(2.79)\end{array}$ & $\begin{array}{c}0.0003^{* *} \\
(2.66)\end{array}$ \\
\hline Percent $<$ age 5 & $\begin{array}{c}-1.0145 \\
(1.31)\end{array}$ & $\begin{array}{c}0.6960 \\
(1.00)\end{array}$ & $\begin{array}{c}0.6960 \\
(1.29)\end{array}$ & $\begin{array}{c}0.0266 \\
(0.04)\end{array}$ \\
\hline Percent $>$ age $5 \&<$ age 19 & $\begin{array}{c}0.7426 \\
(1.40)\end{array}$ & $\begin{array}{c}-0.4559 \\
(1.26)\end{array}$ & $\begin{array}{c}-0.4559 * \\
(1.98)\end{array}$ & $\begin{array}{c}-0.3040 \\
(0.79)\end{array}$ \\
\hline Percent $>$ age 65 & $\begin{array}{c}0.0609 \\
(0.09)\end{array}$ & $\begin{array}{c}0.1603 \\
(0.45)\end{array}$ & $\begin{array}{c}0.1603 \\
(0.38)\end{array}$ & $\begin{array}{c}0.1301 \\
(0.33)\end{array}$ \\
\hline Average local government wage & $\begin{array}{c}0.0001^{* *} \\
(4.09)\end{array}$ & $\begin{array}{c}0.0000 \\
(1.59)\end{array}$ & $\begin{array}{c}0.0000 \\
(1.56)\end{array}$ & $\begin{array}{c}0.0000 \\
(1.88)\end{array}$ \\
\hline Employment, per capita & $\begin{array}{c}0.3623^{* *} \\
(3.84)\end{array}$ & $\begin{array}{c}-0.0371 \\
(0.45)\end{array}$ & $\begin{array}{c}-0.0371^{*} \\
(2.33)\end{array}$ & $\begin{array}{c}-0.0483 \\
(0.52)\end{array}$ \\
\hline Population growth & $\begin{array}{c}0.2927 \\
(0.71)\end{array}$ & $\begin{array}{c}-1.2501^{* *} \\
(4.06)\end{array}$ & $\begin{array}{c}-1.2501^{* *} \\
(3.60)\end{array}$ & $\begin{array}{c}-1.2753^{* *} \\
(4.84)\end{array}$ \\
\hline Functional performance index & $\begin{array}{c}0.0003^{* *} \\
(13.91)\end{array}$ & $\begin{array}{c}0.0002^{* *} \\
(6.72)\end{array}$ & $\begin{array}{c}0.0002^{* *} \\
(18.69)\end{array}$ & $\begin{array}{c}0.0002^{* *} \\
(6.63)\end{array}$ \\
\hline General purpose govt, per capita & $\begin{array}{c}0.0708^{* *} \\
(3.72)\end{array}$ & $\begin{array}{c}0.0722 \\
(0.87)\end{array}$ & $\begin{array}{c}0.0722^{*} \\
(2.10)\end{array}$ & $\begin{array}{c}0.0190 \\
(0.25)\end{array}$ \\
\hline Special purpose govt, per capita & $\begin{array}{c}0.0794^{* *} \\
(3.29)\end{array}$ & $\begin{array}{c}0.0047 \\
(0.22)\end{array}$ & $\begin{array}{c}0.0047 \\
(0.58)\end{array}$ & $\begin{array}{c}-0.0241 \\
(0.93)\end{array}$ \\
\hline State aid, per capita & $\begin{array}{c}0.0003^{* *} \\
(5.83)\end{array}$ & $\begin{array}{c}0.0003^{* *} \\
(4.36)\end{array}$ & $\begin{array}{c}0.0003^{* *} \\
(10.50)\end{array}$ & $\begin{array}{c}0.0003^{* *} \\
(4.19)\end{array}$ \\
\hline Federal aid, per capita & $\begin{array}{c}0.0003^{*} \\
(2.24)\end{array}$ & $\begin{array}{c}0.0003^{* *} \\
(3.94)\end{array}$ & $\begin{array}{c}0.0003^{* *} \\
(6.04)\end{array}$ & $\begin{array}{c}0.0003^{* *} \\
(3.89)\end{array}$ \\
\hline $\mathrm{N}$ & 7,670 & 7,670 & 7,670 & 7,670 \\
\hline Within R-squared & 0.5338 & 0.2754 & 0.7315 & 0.3119 \\
\hline County FE? & No & Yes & Yes & Yes \\
\hline Year FE? & Yes & Yes & Yes & Yes \\
\hline State Trend? & No & No & No & Yes \\
\hline
\end{tabular}




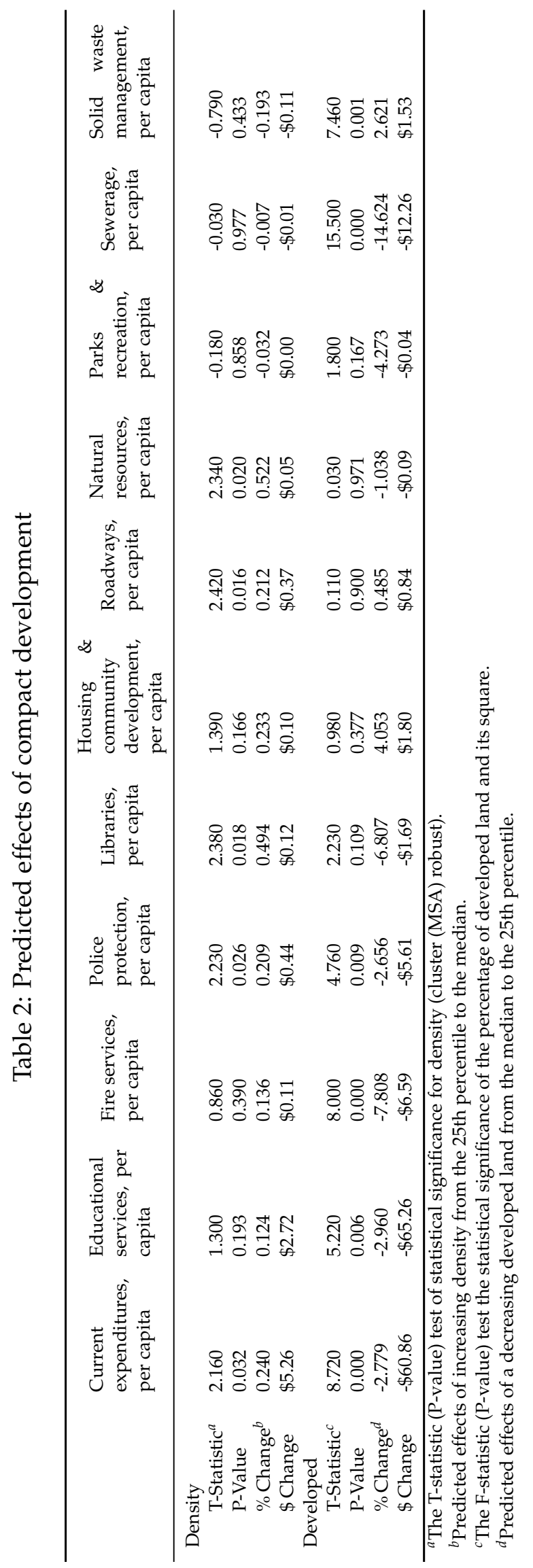



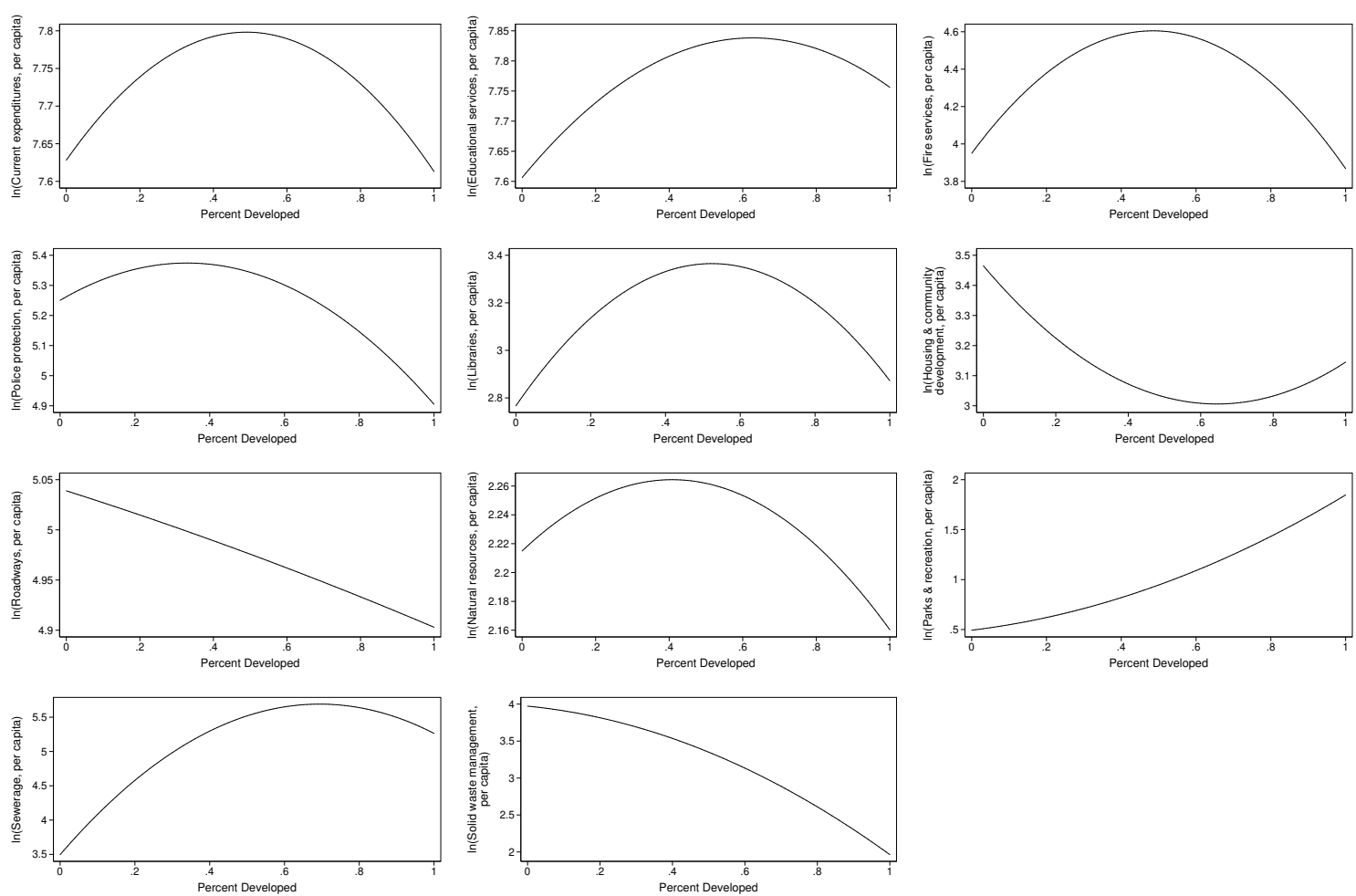

Figure 2: Quadratic Effects

per capita; however, there is a strong nonlinear effect of the spatial extent of development. One might expect for any given level of density per capita fire costs are relatively constant. Covering a larger spatial area requires more inputs in terms of stations, trucks, and firefighters. The scattered nature of suburban development also makes efficient placement of capital assets difficult further increasing costs. As can be seen in figure 2, per capita expenditures increase with development until 48.5 percent development and fall after. Therefore, for a given number of residents, the cost per resident is higher as individuals are more unevenly spread out and fall when they are more uniformly distributed. However, another public safety function, police protection expenditures, is influenced by both density and spatial development. As density rises, so too does police expenditures suggesting more difficulty in policing a denser area. A similar story to fire protection can be told about the spatial extent of development with regard to policing. Adequately policing a community that is spatially large likely requires more inputs per capita.

The results presented here are mostly a departure from Carruthers and Úlfarsson (2008) who finds that density is an important factor in nearly every policy area. These results put significantly more weight on the non-linear role of developed land. These differences are likely derived from a difference in sample selection and Carruthers and Úlfarsson lack of cross-sectional, time series data. 


\section{Policy Implications}

This analysis utilizes a cross-sectional, time-series approach to examine the relationship between two aspects of urban development and per capita current expenditures. The extant literature suggests two potential relationships. First, more compact development could lead to lower levels of per capita expenditures because of scale economies, more efficient placement of capital facilities, and less duplication in service delivery. However, the "harshness" of the urban environment could lead to higher per capita expenditures; it is more expensive to provide services in compact, dense areas. Using a fixed effects regression, this analysis helps to disentangle these two disparate lines of research. If urban sprawl does inflate per capita expenditures, policies that aim to reduce sprawl such as urban growth boundaries, impact fees, or reforming local zoning ordinances have some additional justification.

In general, this analysis finds that increasing density leads to higher per capita expenditures; however, the effect size is quantitatively small across all specifications. This positive result gives some credence to the suggestion that areas with higher density also have higher per capita expenditures because of "urban harshness" (Ladd 1992). However, holding density constant, per capita expenditures can be reduced by limiting the spatial extent of development. The problem appears to be confined to leapfrog development. Results from Ihlanfeldt and Willardsen (2018) suggest the same. As development becomes more uniform across a county, public service costs are reduced. This suggests that in-fill development policies and other similar land use policies can be an effective tool in helping to keep local government spending down. This result for limiting leapfrog development as a means to lower per capita expenditures is not uniform across spending categories. The greatest reductions are confined to categories with large fixed assets such as schools, fire protection, and sewers.

From a policy perspective, these results suggest that the median urban county area could experience a decrease in per capita expenditures by encouraging more compact development patterns. However, the practical effects are modest. As shown in table 2, moving from the 25th percentile in density to the median increases per capita current expenditures by $\$ 5.26$. This represents a 0.24 percent increase from the median level of per capita current expenditures. However, moving from the median in developed land to the 25th percentile (increasing compactness) lowers per capita current expenditures by $\$ 60.86$ on average. This is a reduction from the median level of per capita current expenditures at 2.78 percent but still remains a small fraction of overall per capita direct expenditures. Many expenditure categories have larger predicted effects with those requiring service provision over spatially large areas seeing the largest benefits from compact development. Among those results statistically significant in table 2, education, fire services, police protection, and sewerage all are predicted to see declines in per capita expenditures of more than three percent if developed land is decreased from the median to the 25 th percentile. The increase in per capita expenditures associated with an increase in density is quite small in relation to the reductions associated with developed land.

If the goal of state and local policymakers is to reduce the fiscal cost of sprawl, this analysis suggests adopting policies that reduce the potential for inefficient development on the urban fringe would be fruitful. Increased density is likely to follow, but the increase in public spending is small in relation. Previous research has suggested that more compact development can be encouraged through the appropriate use of impact fees (Brueckner 1997) by internalizing the cost of more sprawling development through an increase in development price, though there is disagree- 
ment in the literature (Burge and Ihlanfeldt 2006). To the extent that such a policy does discourage inefficient development on the urban fringe, this analysis suggests that the local governments in the area are likely to see reduced per capita expenditures. Additionally, statewide growth management or local urban containment policies may be a mechanism to reduce growth on the urban fringe (Wassmer 2006). However, statewide plans must be vertically integrated (requiring local plans to conform with state plans) or local plans must be horizontally integrated (requiring geographically contiguous local plans to be consistent). As Wassmer (2006) notes, it is unclear whether such plans can stem sprawling development or simply shift development to more ex-urban areas, making the problem worse. Adding some evidence to this possibility, Carruthers and Úlfarsson (2002) suggest that restrictive land use regulations are likely to push development to less restrictive areas, usually beyond the urban fringe. Alternatively, Paulsen (2014) suggests that in states with a substantial role in the planning process have higher levels of infill development, helping to stem inefficient development on the urban fringe. Such that statewide planning or local urban containment policies are effective in restraining growth on the urban fringe, this analysis suggests that local government expenditures are likely to be reduced as a result. ${ }^{19}$

This analysis adds to a growing literature suggesting that both the vertical (density) and horizontal (percent developed) aspects of development are important in the estimation of the costs of sprawl (Carruthers and Úlfarsson 2003, 2008; Goodman 2012). However, inadequate crosssectional, time-series data hinders our ability to properly measure the horizontal aspects of development. Developed land is a proxy for what researchers would rather measure, the continuousness of development over the urban landscape. Hortas-Rico and Solé-Ollé (2010) get much closer to actually measuring this concept using the percentage of development that is scattered rather than compact. Similarly, Ihlanfeldt and Willardsen (2018) measure the gini coefficient of building structures. However, this are reasonably unique data sets. Multispectral satellite imagery provides an opportunity to enhance our ability to measure such a variable consistently and over time to track changes in land use patterns. These data sets are just coming online and present a great opportunity to move beyond the current limitations in the literature.

\section{References}

Baum-Snow, Nathaniel. 2007a. "Did Highways Cause Suburbanization?" Quarterly Journal of Economics 122 (2): 775-805.

— . 2007b. "Suburbanization and transportation in the monocentric model." Journal of Urban Economics 62 (3): 405-423.

Bergstrom, Theodore C., and Robert P. Goodman. 1973. "Private Demands for Public Goods." American Economic Review 63 (3): 280-296.

Berry, Christopher R. 2009. Imperfect Union: Representation and Taxation in Multilevel Governments. Cambridge: Cambridge University Press.

Borcherding, Thomas E., and Robert T. Deacon. 1972. "The demand for the services of non-federal governments." American Economic Review 62 (5): 891-901.

\footnotetext{
${ }^{19}$ It is important to note that adopting policies that restrict growth on the urban fringe without a relaxation of restrictions on density inside the urban area will necessarily lead to restrictions in the supply of housing inside the urban area. In areas with positive population growth, the result is higher housing prices and a potential loss in consumer surplus.
} 
Bradbury, Katharine L., et al. 1984. "State Aid to Offset Fiscal Disparities Across Communities." National Tax Journal 37 (2): 151-170.

Bradford, David F., Richard A. Malt, and Wallace E. Oates. 1969. "The rising cost of local public services: some evidence and reflections." National Tax Journal 22 (2): 185-202.

Brueckner, Jan K. 1997. "Infrastructure financing and urban development: The economics of impact fees." Journal of Urban Economics 66 (3): 383-407.

— . 2000. “Urban Sprawl: Diagnosis and Remedies." International Regional Science Review 23 (2): 160-171.

Brueckner, Jan K., and David A. Fansler. 1983. "The economics of urban sprawl: Theory and evidence on the spatial sizes of cities." The Review of Economics and Statistics 65 (3): 479-482.

Brueckner, Jan K., and Hyun-A A. Kim. 2003. "Urban sprawl and the property tax." International Tax and Public Finance 10 (1): 5-23.

Burbridge, John B., Lonnie Magee, and A. Leslie Robb. 1988. “Alternative transformation to handle extreme values of the dependent variable." Journal of the American Statistical Association 83 (401): 123-127.

Burchfield, Marcy, et al. 2006. “Causes of sprawl: a portrait from space." Quarterly Journal of Economics 121 (2): 587-633.

Burge, Gregory, and Keith R. Ihlanfeldt. 2006. "Impact fees and single-family home construction." Journal of Urban Economics 60 (2): 284-306.

Carruthers, John I., and Gudmundur F. Úlfarsson. 2002. "Fragmentation and sprawl: evidence from interregional analysis." Growth and Change 33 (3): 312-340.

— . 2003. "Urban sprawl and the cost of public services." Environment and Planning B: Planning and Design 30 (4): 503-522.

— . 2008. "Does 'smart growth' matter to public finance?" Urban Studies 45 (9): 1791-1823.

Driscoll, John C., and Aart C. Kraay. 1998. “Consistent Covariance Matrix Estimation with Spatially Dependent Panel Data." Review of Economics and Statistics 80 (4): 549-560.

Duany, Andres, Elizabeth Plater-Zyberk, and Jeff Speck. 2000. Suburban Nation: The Rise of Sprawl and the Decline of the American Dream. New York: North Point Press.

Ewing, Reid. 1994. "Characteristics, causes, and effects of sprawl: A literature review." Environmental and Urban Studies 21 (2): 1-15.

Galster, George, et al. 2001. "Wrestling sprawl to the ground: Defining and measuring an elusive concept." Housing Policy Debate 12 (4): 681-717.

Glaeser, Edward L., and Matthew E. Kahn. 2006. "Sprawl and urban growth." In Handbook of regional and urban economics, ed. by J. Vernon Henderson and Jacques Francois Thisse, 4:24812527. Amsterdam: Holland-North.

Goodman, Christopher B. 2012. Density, Population Growth and Local Government Finance. Unpublished Dissertation, University of Georgia.

Holcombe, Randall G., and DeEdgra W. Williams. 2008. "The impact of population density on municipal government expenditures." Public Finance Review 36 (3): 359-373. 
Hortas-Rico, Miriam, and Albert Solé-Ollé. 2010. "Does urban sprawl increase the costs of providing local public services? Evidence from Spanish municipalities." Urban Studies 47 (7): 15131540 .

Ihlanfeldt, Keith R., and Kevin Willardsen. 2018. "Local Public Services Costs and the Geography of Development: Evidence from Florida Counties." Journal of Regional Science 58 (1): 5-37.

Ladd, Helen F. 1992. "Population growth, density and the costs of providing public services." Urban Studies 29 (2): 273-295.

- . 1994. "Fiscal impacts of local population growth: A conceptual and empirical analysis." Regional Science and Urban Economics 24 (6): 661-686.

— . 1998. "Land Use Regulation as a Fiscal Tool." In Local Government Tax and Land Use Policies: Understanding the Links, ed. by Helen F. Ladd. Cheltenham, UK: Edward Elgar.

Ladd, Helen F., and John M. Yinger. 1989. America's Ailing Cities: Fiscal Health and the Design of Urban Policy. Baltimore: Johns Hopkins University Press.

Leik, Robert K. 1966. “A Measure of Ordinal Consensus.” Pacific Sociological Review 9 (2): 85-90.

McIntosh, Craig T., and Wolfram Schlenker. 2006. "Indentifying Non-Linearities in Fixed Effects Models." Working paper.

Mieszkowski, Peter, and Edwin S. Mills. 1993. "The causes of metropolitan suburbanization." The Journal of Economic Perspectives 7 (3): 135-147.

Nechyba, Thomas J., and Randall P. Walsh. 2004. "Urban Sprawl." Journal of Economic Perspectives 18 (4): 177-200.

Nusser, Sarah M., and Jeff J. Goebel. 1997. “The National Resource Inventory: A Long-Term MultiResouce Monitoring Programme." Environmental and Ecological Statistics 4 (3): 181-204.

Paulsen, Kurt. 2014. “Geography, policy, or market? New evidence on the measurement and causes of sprawl (and infill) in US metropolitan regions." Urban Studies 51 (12): 2629-2645.

Pendall, Rolf. 1999. “Do land-use controls cause sprawl?" Environment and Planning B: Planning and Design 26 (4): 555-571.

Real Estate Research Corporation. 1974. The costs of sprawl: Environmental and economic costs of alterative development patters at the urban fringe. Washinton D.C.: Council on Environmental Quality; Department of Housing / Urban Development; Environmental Protection Agency.

Song, Yan, and Yves Zenou. 2006. "Property tax and urban sprawl: Theory and implications for US cities." Journal of Urban Economics 60 (3): 519-534.

Wassmer, Robert W. 2006. "The Influence of Local Urban Containment Policies and Statewide Growth Management on the Size of United States Urban Areas." Journal of Regional Science 46 (1): 25-65.

— . 2008. "Causes of Urban Sprawl in the United States: Auto reliance as compared to natural evolution, flight from blight, and local revenue reliance." Journal of Policy Analysis and Management 27 (3): 536-555.

Wolman, Harold, et al. 2005. "The Fundamental Challenge in Measuring Sprawl: Which Land Should Be Considered?" The Professional Geographer 57 (1): 94-105. 
Wooldridge, Jeffrey M. 2010. Econometric Analysis of Cross Section and Panel Data. 2nd ed. Cambridge, MA: MIT Press. 


\section{Appendices}

Table A1: Dependent variable definitions and means

\begin{tabular}{|c|c|c|c|c|c|}
\hline Variable & Definition & Mean & St. Dev. & Min & Max \\
\hline $\begin{array}{l}\text { Current expenditures, } \\
\text { per capita }\end{array}$ & $\begin{array}{l}\text { Total current expenditures divided by } \\
\text { population; Source: U.S. Census Bureau }\end{array}$ & $\$ 2,401.77$ & $\$ 1,462.70$ & $\$ 38.15$ & $\$ 47,548.62$ \\
\hline $\begin{array}{l}\text { Educational services, per } \\
\text { capita }\end{array}$ & $\begin{array}{l}\text { Current expenditures for primary and } \\
\text { secondary education divided by popula- } \\
\text { tion; Source: U.S. Census Bureau }\end{array}$ & $\$ 1,156.56$ & $\$ 460.17$ & $\$ 0.00$ & $\$ 10,840.68$ \\
\hline Fire services, per capita & $\begin{array}{l}\text { Current expenditures for fire services di- } \\
\text { vided by population; Source: U.S. Census } \\
\text { Bureau }\end{array}$ & $\$ 53.59$ & $\$ 51.83$ & $\$ 0.00$ & $\$ 952.70$ \\
\hline $\begin{array}{l}\text { Police protection, per } \\
\text { capita }\end{array}$ & $\begin{array}{l}\text { Current expenditures for police protec- } \\
\text { tion divided by population; Source: U.S. } \\
\text { Census Bureau }\end{array}$ & $\$ 121.10$ & $\$ 86.95$ & $\$ 0.00$ & $\$ 2,559.61$ \\
\hline Libraries, per capita & $\begin{array}{l}\text { Current expenditures for library services } \\
\text { divided by population; Source: U.S. Cen- } \\
\text { sus Bureau }\end{array}$ & $\$ 16.53$ & $\$ 17.26$ & $\$ 0.00$ & $\$ 354.07$ \\
\hline $\begin{array}{l}\text { Housing \& community } \\
\text { development, per capita }\end{array}$ & $\begin{array}{l}\text { Current expenditures for housing and } \\
\text { community development divided by } \\
\text { population; Source: U.S. Census Bureau }\end{array}$ & $\$ 38.34$ & $\$ 59.23$ & $\$ 0.00$ & $\$ 2,115.93$ \\
\hline Roadways, per capita & $\begin{array}{l}\text { Current expenditures for highway provi- } \\
\text { sion divided by population; Source: U.S. } \\
\text { Census Bureau }\end{array}$ & $\$ 101.14$ & $\$ 72.36$ & $\$ 0.00$ & $\$ 962.22$ \\
\hline $\begin{array}{l}\text { Natural resources, per } \\
\text { capita }\end{array}$ & $\begin{array}{l}\text { Current expenditures for natural re- } \\
\text { source management divided by popula- } \\
\text { tion; Source: U.S. Census Bureau }\end{array}$ & $\$ 13.31$ & $\$ 42.51$ & $\$ 0.00$ & $\$ 2,079.49$ \\
\hline $\begin{array}{l}\text { Parks \& recreation, per } \\
\text { capita }\end{array}$ & $\begin{array}{l}\text { Current expenditures for parks and recre- } \\
\text { ation divided by population; Source: U.S. } \\
\text { Census Bureau }\end{array}$ & $\$ 1.53$ & $\$ 4.32$ & $\$ 0.00$ & $\$ 126.92$ \\
\hline Sewerage, per capita & $\begin{array}{l}\text { Current expenditures for sewerage di- } \\
\text { vided by population; Source: U.S. Census } \\
\text { Bureau }\end{array}$ & $\$ 50.00$ & $\$ 45.77$ & $\$ 0.00$ & $\$ 1,134.40$ \\
\hline $\begin{array}{l}\text { Solid waste manage- } \\
\text { ment, per capita }\end{array}$ & $\begin{array}{l}\text { Current expenditures for solid waste } \\
\text { management divided by population; } \\
\text { Source: U.S. Census Bureau }\end{array}$ & $\$ 37.30$ & $\$ 36.13$ & $\$ 0.00$ & $\$ 681.52$ \\
\hline
\end{tabular}


Table A2: Independent variables definitions and means

\begin{tabular}{|c|c|c|c|c|c|}
\hline Variable & Definition & Mean & St. Dev. & Min & Max \\
\hline \multicolumn{6}{|l|}{ Urban development variables } \\
\hline Density & $\begin{array}{l}\text { Population plus employment divided by NRI } \\
\text { urban land; Source: U.S. Department of Agri- } \\
\text { culture and U.S. Census Bureau }\end{array}$ & 5.695 & 18.370 & 0.000 & 684.153 \\
\hline Percent developed & $\begin{array}{l}\text { NRI urban land divided by total land; Source: } \\
\text { U.S. Department of Agriculture }\end{array}$ & $13.297 \%$ & $16.410 \%$ & $0.000 \%$ & $99.644 \%$ \\
\hline \multicolumn{6}{|c|}{ Demand $\mathcal{E}$ variation in demand variables } \\
\hline Personal income, per capita & $\begin{array}{l}\text { Personal income }(\$ 1,000 \text { s) divided by popula- } \\
\text { tion; Source: Bureau of Economic Analysis and } \\
\text { U.S. Census Bureau }\end{array}$ & $\$ 27.08$ & $\$ 8.45$ & $\$ 8.05$ & $\$ 109.21$ \\
\hline Percent property tax & $\begin{array}{l}\text { Property tax revenue divided by total own- } \\
\text { source revenue; Source: U.S. Census Bureau } \\
\text { Leik index of race (white, black and other); }\end{array}$ & $42.690 \%$ & $16.880 \%$ & $2.224 \%$ & $91.472 \%$ \\
\hline Variation in race & $\begin{array}{l}\text { Source: Surveillance, Epidemiology, and End } \\
\text { Results (SEER), National Cancer Institute } \\
\text { Leik index of age ( } 5 \text { year increments); Source: }\end{array}$ & 0.149 & 0.135 & 0.002 & 0.818 \\
\hline Variation in age & $\begin{array}{l}\text { Surveillance, Epidemiology, and End Results } \\
\text { (SEER), National Cancer Institute }\end{array}$ & 0.415 & 0.027 & 0.188 & 0.497 \\
\hline \multicolumn{6}{|c|}{ (c) } \\
\hline Population (1000s) & $\begin{array}{l}\text { Population in 1,000s; Source: U.S. Census Bu- } \\
\text { reau }\end{array}$ & 200.083 & 480.731 & 0.839 & 9962.790 \\
\hline Percent $<$ age 5 & $\begin{array}{l}\text { Percentage of total population } 5 \text { years and } \\
\text { younger; Source: Surveillance, Epidemiology, } \\
\text { and End Results (SEER), National Cancer In- } \\
\text { stitute }\end{array}$ & $6.961 \%$ & $1.190 \%$ & $0.980 \%$ & $14.649 \%$ \\
\hline Percent $>$ age $5 \&<$ age 19 & $\begin{array}{l}\text { Percentage of total population between ages } \\
5 \text { and 19; Source: Surveillance, Epidemiology, } \\
\text { and End Results (SEER), National Cancer Insti- } \\
\text { tute }\end{array}$ & $22.087 \%$ & $2.661 \%$ & $2.637 \%$ & $37.575 \%$ \\
\hline Percent $>$ age 65 & $\begin{array}{l}\text { Percentage of total population older than 65; } \\
\text { Source: Surveillance, Epidemiology, and End } \\
\text { Results (SEER), National Cancer Institute }\end{array}$ & $12.908 \%$ & $3.726 \%$ & $0.886 \%$ & $49.292 \%$ \\
\hline $\begin{array}{l}\text { Average local government } \\
\text { wage }\end{array}$ & $\begin{array}{l}\text { Total full-time monthly payrolls for local gov- } \\
\text { ernment employees divided by total full time } \\
\text { employees (measured in March); Source: U.S. } \\
\text { Census Bureau }\end{array}$ & $\$ 2,946.86$ & $\$ 708.69$ & $\$ 725.78$ & $\$ 17,062.60$ \\
\hline Employment, per capita & $\begin{array}{l}\text { Jobs by place divided by population; Source: } \\
\text { Bureau of Economic Analysis and U.S. Census } \\
\text { Bureau }\end{array}$ & 0.381 & 0.152 & 0.036 & 3.081 \\
\hline Population growth & $\begin{array}{l}\text { Compound annualized growth rate of popula- } \\
\text { tion; Source: U.S. Census Bureau }\end{array}$ & $1.241 \%$ & $1.621 \%$ & $-27.462 \%$ & $11.680 \%$ \\
\hline \multicolumn{6}{|c|}{ Service delivery responsibility variables } \\
\hline $\begin{array}{l}\text { Functional performance in- } \\
\text { dex }\end{array}$ & $\begin{array}{l}\text { See text for explanation; Source: U.S. Census } \\
\text { Bureau }\end{array}$ & $\$ 2,228.00$ & $\$ 560.89$ & $\$ 877.03$ & $\$ 3,409.33$ \\
\hline $\begin{array}{l}\text { General purpose govern- } \\
\text { ments, per capita }\end{array}$ & $\begin{array}{l}\text { Number of cities and towns (where applicable) } \\
\text { divided by population (1000s); Source: U.S. } \\
\text { Census Bureau. }\end{array}$ & 0.225 & 0.370 & 0.000 & 3.886 \\
\hline $\begin{array}{l}\text { Special purpose govern- } \\
\text { ments, per capita }\end{array}$ & $\begin{array}{l}\text { Number of special districts divided by popula- } \\
\text { tion (1000s); Source: U.S. Census Bureau. } \\
\text { Intergovernmental aid from state sources di- }\end{array}$ & 0.207 & 0.328 & 0.000 & 4.946 \\
\hline State aid, per capita & $\begin{array}{l}\text { vided by population; Source: U.S. Census Bu- } \\
\text { reau }\end{array}$ & $\$ 995.02$ & $\$ 517.34$ & $\$ 22.55$ & $\$ 13,720.10$ \\
\hline Federal aid, per capita & $\begin{array}{l}\text { Intergovernmental aid from federal sources di- } \\
\text { vided by population; Source: U.S. Census Bu- } \\
\text { reau }\end{array}$ & $\$ 91.58$ & $\$ 112.60$ & $\$ 0.00$ & $\$ 2,914.54$ \\
\hline
\end{tabular}




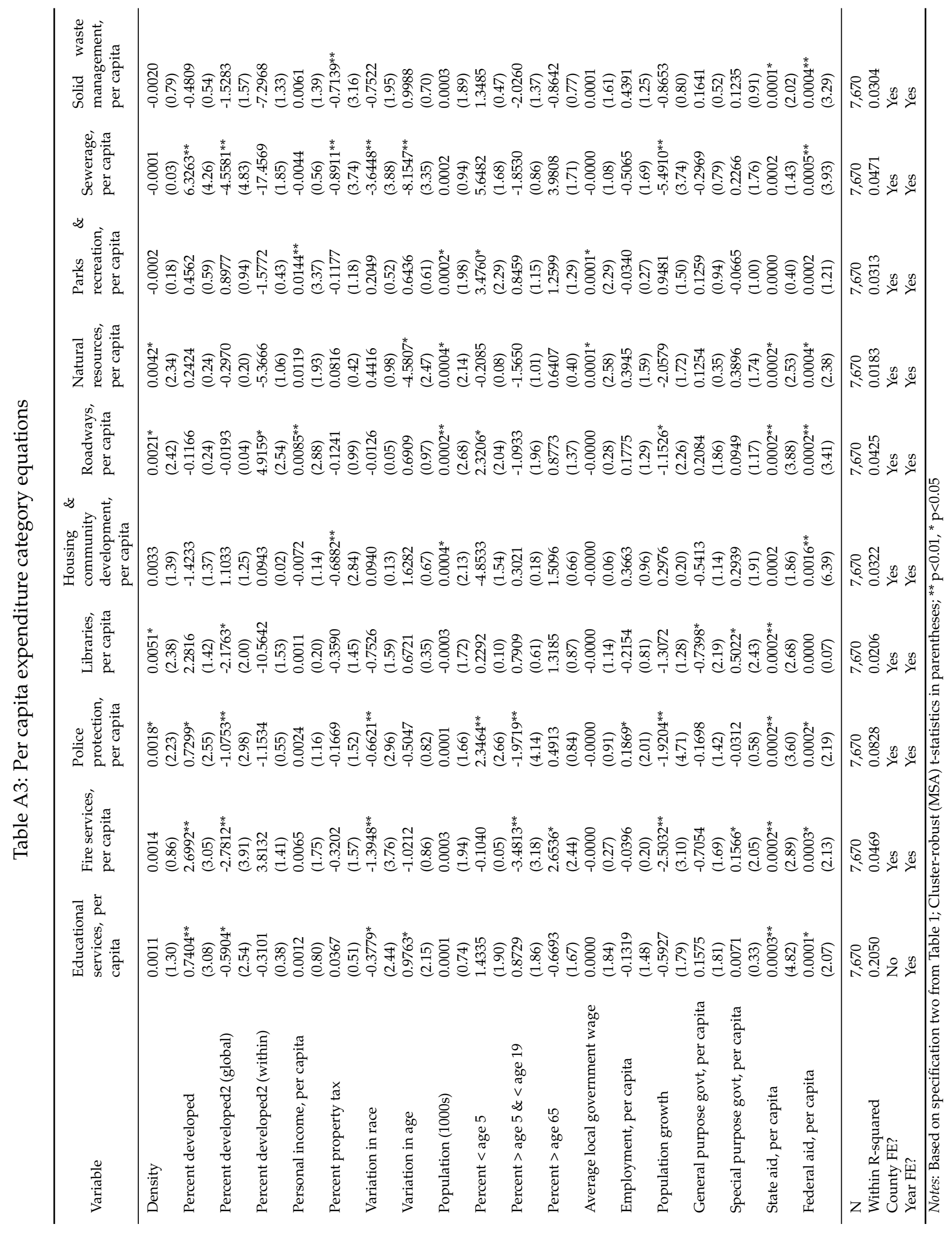

